\title{
電気二重層キャパシタを用いた蓄電装置の 課題と展望
}

キーワード

電気二重層, キャパシタ, 蓄電, 電子回路, 二次電池
岡 村 赵夫

(株) 岡村研究所
電気二重層キャパシタによる蓄電装置について $\operatorname{ECS}^{(1,2)}$ を例にして，その先の展開を専門的な角度から述べる。 基碇的なことや位置づけ，情勢については本誌「学生の ページ」(1)に記したので参照して頂きたい。

\section{1. 発想の出発点}

人は $\operatorname{ECS}$ の技術を“常識の反対”と思えば分かりやす いという。これが本稿のキーワードかも知れない。

まず，キャパシタで二次電池に代る蓄電装置ができる はずだと考えた。その鍵はエネルギ一密度で，それが一 定の水準を超えないと他にどんな長所があっても実用価 值が出ない。それを越えれば最良の二次電池を凌がなく ても，他の長所で特徵を発揮できると見込んだ。

実現の方法も変わっていた。単なるキャパシタの改善 では無理だと考え，図 1 のようにキャパシタに電子回路 を組み合わせ，電子回路で解決できる問題は回路に任せ て，キャパシタはエネルギー密度を増すことに集中した。 その結果, ECS はキャパシタ単独では性能が出ないが, 電子回路と組み合わせて目的を達する方式となった。

\section{2. キャパシタ充放電効率とその改善}

世間には電気二重層キャパシタの内部抵抗の低減に没 頭した研究は多く(3),電気二重層キャパシタは内部抵抗が 低いから充電制御が不要になる‥」とたた例もある。キ ヤパシタの直列抵抗分は損失の原因なので，最優先でそ の低減を目指すのが常識であった。

\section{1 高い内部抵抗と電流源による充放電}

こっでもECSは逆方向へ進んだ。キャパシタの内部抵 抗を低く作ろうとするとエネルギー密度も低下する。抵 抗の大きなキャパシ夕は損失が大きそうだが，それは同 じ電流を流した場合であり，使用条件が許す限りの最小 電流で充放電すれば内部抵抗の高いキャパシタでも充分 に高効率 (文献(1)図 5) となる。

その関係は静電容量 $C$, 内部抵抗 $R$ とすると, 時間 $t$ で全容量を定電流充電した際の効率 $p$ は式(1), 放電は式 (2)で得られ，效率 70\%以上で二式はほとんど重なる。

$$
p=t /(2 C R+t) \ldots \ldots .(1) \quad p=(t-2 C R) / t \ldots \ldots(2)
$$
上の関係は電気工学の計算(2)で導け特別なものではな
いが，その意味するところは電気二重層キャパシタ研究 者にとって，コペルニクス的転回であったはずだ。それ まで低抵抗化が最優先であった内部抵抗が高くてよいな ら，エネルギ一密度は何倍もの问上が可能となる。

なおキャパシタと定電圧源間での充放電は, 内部抵抗 が低くても効率は片道 $50 \%$ となる(2)。これを改善する手 段の一つは, 充放電をスイッチングコンバータ「電流ポ ンプ」を通して出入する電力を電流源 $(2,4)$ 上すればよい。 そこに $(1,2)$ 式を用い実用上許される最長時間，最小電流 になるよう充放電電流を制御すると高効率が得られる。

電流ポンプはキャパシタに電流を出し入れするゴムホ 一スのように使う。効率が 95\%でも往復では $90 \%$ となり， 特に広い電圧範囲, 負荷変動範囲に渡り高効率にするこ とが不可欠だから，近年のパワーエレクトロニクスの進 歩に格好の課題でもある。

\section{2 バンク切換え}

バンク切換え（文献(1)図 4) と呼ぶ手法(2)も実用化され た。キャパシタの充放電効率低下の原因はその端子電圧 が大きく変わることにある。満充電では 2 個のキャパシ 夕を並列にしてスタートし電圧が半分になったところで 直列にすれば $1 / 4$ 電圧まで使っても合成電圧の変動幅は $1 / 2$ ですむ。多段切換えにすると図 2 のように変動幅は小 さく抑えられるから，充電器側あるいは負荷側につなが る機器, たとえばモータードライバーや交直変換装置の 高効率化や軽量化がもたらされる。

図 1 の構成をバンク切換え方式の 1 ブロックに適用す る場合, 二つの電流ポンプ（充電器および出力コンバー

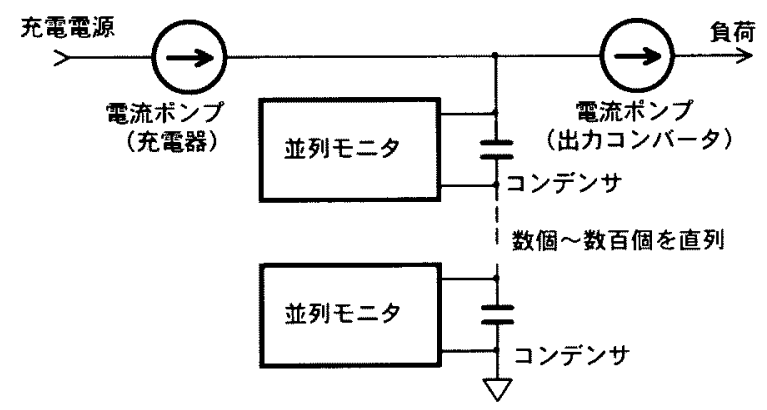

图１新しい蕃電装置“E C S” の基本檕成

R \& D of Capacitor-Electronics Energy Storage System.

By Michio Okamura (Okamura Laboratory, Inc.). 


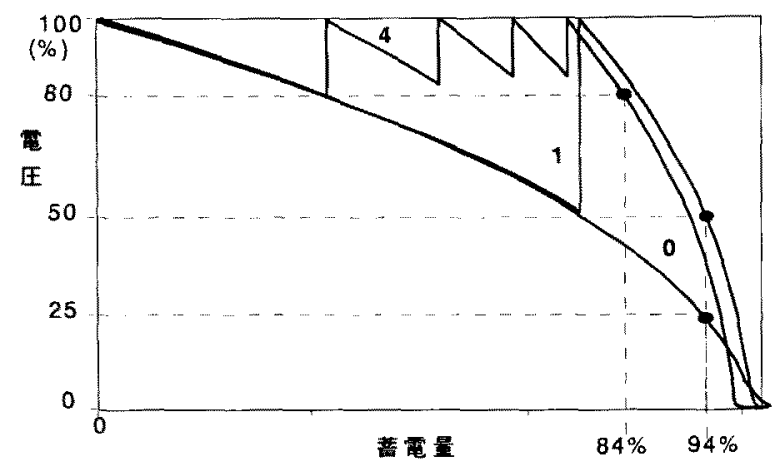

图 2 バンク切換え時の電圧変化 $(0 ， 1 ， 4$ 段)

タ）がバンク切換えのスイッチで置き換わるので，数十 $\mathrm{kW}$ 以上の中〜大型機ではコンバー夕の重量や体積, そし て効率の改善効果も大きい。

\section{3. キャパシタの直列接続問題の解決}

龺列にしたキャパシタの電圧配分の問題は，しばしば 正確に評価されていない。

\section{1 電圧配分の算定}

静電容量 $C_{1} \sim C_{\mathrm{n}}$ 漏れ抵抗 $R_{1} \sim R_{\mathrm{n}}$ のキャパシタを直

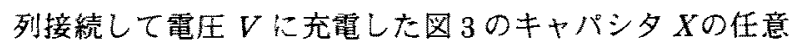
の時間の負担電圧 $V_{\mathbf{x}}$ は, 定数 $k(0 \leq k \leq 1)$ と置くと ${ }^{(2,5)}$,

$$
V_{X}=\left(\frac{k \cdot R_{X}}{R_{1}+\ldots+R_{n}}+\frac{(1-k) \cdot 1 / C_{X}}{1 / C_{1}+\ldots+1 / C_{n}}\right) \cdot V
$$

この結果は電在配分が, 静電容量の逆数と, 漏れ抵抗 のバラッキの和になることを示す。キャバシタのバラッ キとして静電容量土5\%, その温度と経時变化 $\pm 5 \%$, 漏れ 抵抗土10\%亡見積もれば，使用電圧を約 $70 \%$ にする必要 があり，蓄電できる容量は $49 \%$ 亡なる。

キャパシタを安全に直列にする方法では替から均圧抵 抗が知られており，電池では単電池を選別して容量を合 わせている。だが漏れ電流の10 倍を流す均圧抵抗をつな いでも, 静電容量の偏差は不変で 10 倍の漏れ電流と元の

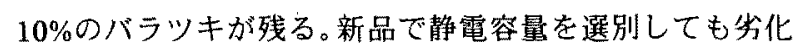
が進むと容量が堿ったセルほど高電圧を急うので「直列 にしたキャパシタは劣化が早い」という現象を生じる。

\section{2 初期化の考え方}

ECS ではこの解決に「並列モ二夕」と呼ぶ電子回路を キャパシ夕に並列に(図 1)取り付ける。これも常識的には
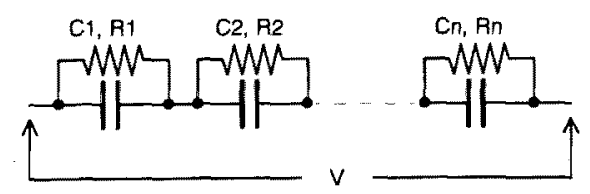

图 3 直列にしたキャパシタの電圧配分の計算

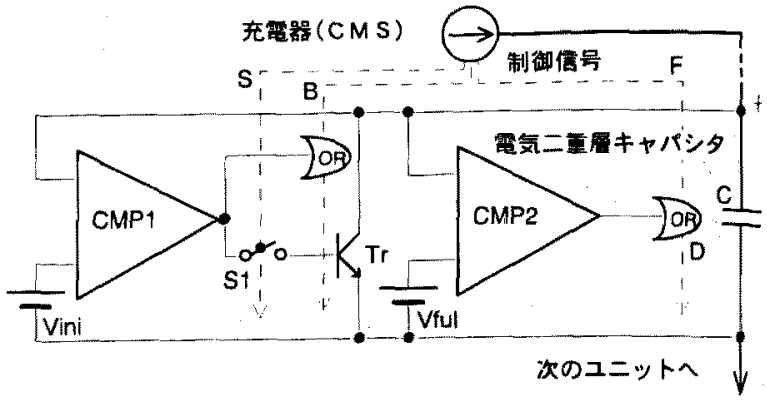

図 4 並列モニタの一例（2コンパレータ式）

不均一なキャパシ夕の漏㣗電流を均一にし，静電容量の バラツキを補い，全部のキャパシ夕をゼロ電压レベルを 基準にして錐かせるべきであろう。だが ECS ではキャバ シタの電圧をゼロレベルでなく「上に揃える」ことにし た。以下の説明は文献(1)図 $3 A, B, C$ を参照頂さたい。

並列モ二タの動作はキャパシタの電圧初期化だと考え ると分かりやすい。総ての単セルのスタート電圧を满充 電電圧に揃え，そこを基準つまり初期化電压として，以 後の放電・充電サイクルを行う。

この方法の顕著な効果は, すバての単セルが漏れ電流 や静電容量上無関係に満充電電圧まで充電されるのでエ ネルギーの利用率が高い。キャパシタは一度初期化され るとその効果法特性が変らない限り何サイクルもズレな い。直列にした静電容量の小さなセル電王は当然ながら 深く，大きいセルは浅く放電するが，初期化電圧まで再 充電されると全セルが等しい電圧に戻る。どのセルも最 大電压は等しく, これ以上の電生は加わらない。

3.3 並列モニタの損失と発熱

キャパシ夕の初期化をいつ行うか活対象とする用途の 動作により, 図 5 の(1)電圧ゼロ，(2)満充電，(3)ハイブリ ッド電気自動車など中間電位に制御し後の充放電に備え る、(4)充電中，(5)放電中，の各種が選べる。(2)以外電 圧が低いところで行うほど電力損失は少ないが, 满充電 電压でセル電圧が等しくなるよう狙って初期化するので セルの静電容量が大きくばらついていると電死の低い方 式ほど遠くから狙うための誤差が大きくなる。

キャパシタの初期化は二次電池のセル容量を等化する のと異なりサイクル毎に行う必要はない。また，使いな がら少しづつ初期化，つまりキャパシタの電生配分を蓚 正していくことも可能である。

回生ブレ一キから $100 \mathrm{~kW}$ の電力で充電されると巨大な 並列モ二タが要ると心配する人がいた。それは大電流の 充放電中は初期化は止めて，閑な時間を待てばよい。

初期化のバラッキも並列モニタから検出する。図 4 で 全キャパシタから満充電信号 $\mathrm{F}$ を例えばワイヤード OR で取り出しておくと, 総充電電圧が満充電電圧の直列也 ル数倍になったとき F が出れば初期化は完全である。

バラツキがあると、総充電電圧がこれより低いところ 


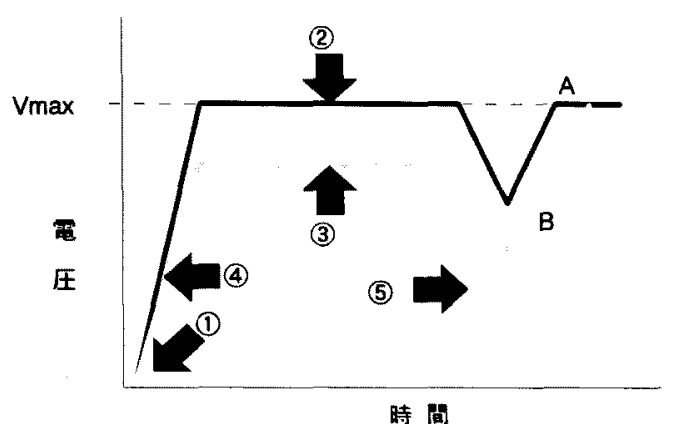

図 5 並列モニタと初期化の場所

でF が出るので初期化の必要性を判定でさる。これらの 動作は充電器あるいは CMS (Capacitor Manegement System)が受け持つ。

\section{4. キャパシタの現実と可能性}

電子回路によって利用率や効率は改善されたが，回路 にエネルギーを蓄えることはできないから，その先のエ ネルギー密度の向上はキャパシタにかかっている。

4. 1 内部抵抗とエネルギー密度

図 6 に ECS 用電気二重層キャパシタの標準型(2)をエネ ルギー密度と, $\Omega$ F で表した内部抵抗 ESR(effective series resistance)の関係で表した。下の放電時間とは定電流で放 電したとき 95\%の効率になる時間である。たとえば PS-L 形は内部抵抗が $2 \Omega \mathrm{F}$ で 1 分間(二次電池の $60 \mathrm{C}$ )で全放電 する放電充で $95 \%$ の効率となる。キャパシタの容量当た りの内部抵抗は二次電池より一桁以上小さく化学反応の 時間を必要としないため, 図の左へ行くほど二次電池に 对して有利となる。

右上がりな 2 本の target 線から分かるように, 内部抵 抗を儀牲にするとエネルギ一密度が大きくできる。ただ し, 内部抵抗を增せ㹥自然にエネルギ一密度が增えるわ けではなく，配線や電極のスペースを切りつめ活性炭も 最適なものを選び, それぞれの条件でギリギリの設計を すると図の程度の差が出るという意味である。

図に二次電池( $\mathrm{Li}$-ion, $\mathrm{Pb}$ acid)のおよその特性を書き込 んだ。キャパシタのエネルギー密度が電池と同じグラフ 上に描けるとは ECS 以前には考えられなかった。二次電 池の特性はエネルギー密度 $40 \mathrm{Wh} / \mathrm{kg}$ 等は $100 \%$ 放電の值 で，寿命は $60 \%$ の放電深度で 300 回など測定条件が一定 しないので，それぞれの放電率での公称エネルギ一密度 に寿命試験の放電深度を掛けた概略值である。

\section{2 エネルギー密度はどこまで出るか}

電気二重層キャパシタのエネルギー密度は耐電圧と静 電容量の 2 方向に発展できる。だが活性炭電極に有機電 解液という現在の組合せは幾つかの課題を背負っている。

先ず酎電圧だが，高活性な触媒である活性炭を電極に して有機電解液を沁み込ませ, 電圧を加えてできるだけ 高電圧まで電気分解を起こさせず, 長期間使おうという

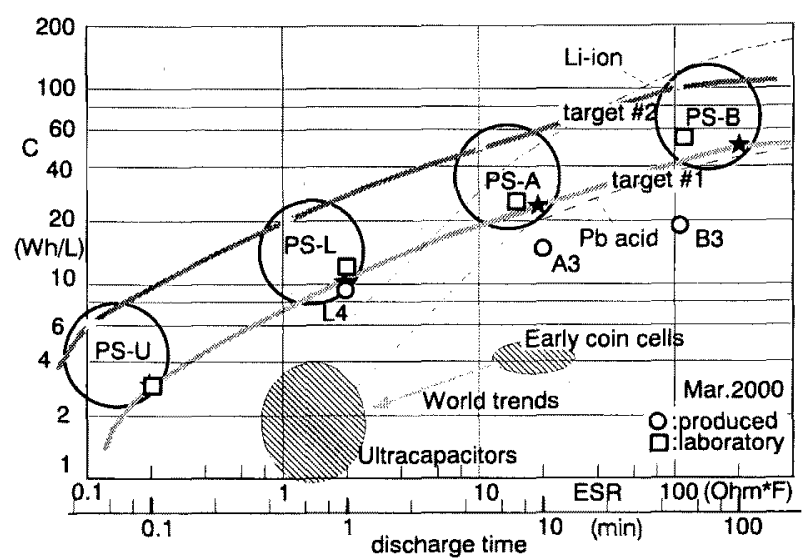

図6ECS用キャパシタのエネルギー密度と内部抵抗

構造上の矛盾がある。多種類の電解液の分解電任が測定 されているが，いずれも不純物のない電極による低い電 流感度でのデータなので, 活性炭電極での実用電圧はそ れらより遥かに低い3V内外に留まっている。

もう一つの静電容量と電極表面の関係も，微細黒鈶構 造のエッジと基底部のように均一な導電性電極面として は扱えない要素があり，静電容量の現れかたに未知の点 が多い。この辺は電気工学上違って未開拓というか, 自 然現象や物性に直接向き合っているためか，据り進む心゙ き鉱脈に素手で触れているような状況にある。

キャパシタでいうと, 低内部抵抗を要求されるハイブ リッド自動車や無停電電源用の PS-L 級で現状で 9Wh/lit, 近い将来に $15 \mathrm{Wh} / \mathrm{lit}$ 程度が実現するであろう。この級の エネルギー密度は低いが,出力密度では $2.5 \mathrm{~kW} / \mathrm{kg}(3.5 \mathrm{~kW}$ lit)を越えており ${ }^{(6)}$ 実用電池より $2 \sim 3$ 倍は大きく, 特性 を正確に理解して使いさえすれば充分な競争力がある。

内部抵抗の大きな PS-B 級では活性炭で $30 \mathrm{Wh} / \mathrm{hit}$, 活 性炭ではない非多孔性 (第二世代) の炭素材料で $50 \mathrm{Wh} / \mathrm{lit}$ 程度 $(2,7)$ が期待できる。PS.L 級に比べて大幅にエネルギ 一密度が向上する理由は，電極構造の高密度化などによ る静電容量密度の向上とともに, 導電率のやや低い, 耐 電压の高い電解液が使用できるからでもある。

\section{5. 応用の経験と展望}

キャパシタによる蓄電装置に ECSのグループだけでも 19 企業の参入を得て, 国や県の補助も受け血税まで使い 開発するにはそれなりの根拠と可能性が必要である。

\section{1 二次電池之の得失}

全容量の放電時間が約 5 分間以下で, 頉繁に充放電を 繰り返す用途では，ECS は現在知られているどの萻電装 置（二次電池，フライホイール， SMES も含めて）より 有利である可能性が大きい。充放電時間が 10 分を越え， さらに 1 時間以上となるとエネルギー密度の点でナトリ ウム硫黄電池や $\mathrm{Li}$ イオン電池が断然優勢となる。 


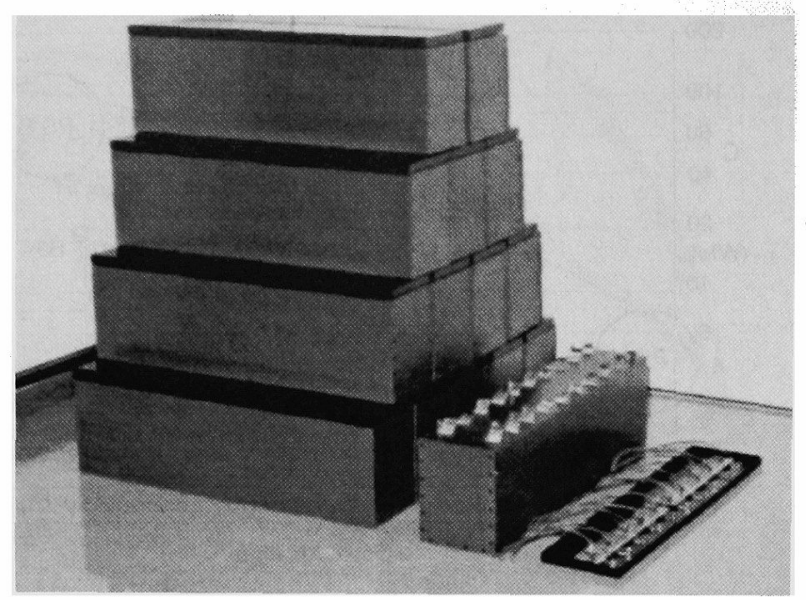

图 7 高エネルギー密度キャパシタモジュール PS-B, 1 lit セル*10

これらに対しキャパシタは何が利点かというと, 充放 電効率とサイクル寿命そして安全性である。電池や擬似 容量のサイクル試験では浅い放電深度や小電流領域で試 験した例が多い。キャパシタは無制限な放電深度と実用 最大の電流で恐らく電池の 10 倍を越える寿命があり, 二 次電池が改善されつつある今日でも明瞭な長所である。

充放電効率は $\mathrm{Li}$ イオン電池以外の二次電池は競争相手 ではない。Li イオン電池もハイブリッド自動車用など高 出力タイプでは内部抵抗による発熱で大きく差がつく。 しかし一晚中充電するような電力貯蔵用では, 自己放電 率がよい Li イオン電池だけは, 他の二次電池を抜いて, キャパシタと甲乙つけがたい充放電効率が得られる。

安全性と信頼性そして睘境負荷に関しては，爆発せず 燃え難く，本質的に劣化しにくいキャパシタが群を抜い ている。しかしこれは個々の製品の品質管理で左右され る要素が大きく, 競合製品は爆発するぞといったのでは 誹謗に当るのでセールスポイントにはしにくい。

\section{2 いくつかの実例}

ECS の動作を実証する充放電キット, 電動自転車, 太 陽光発電と組み合わせた高効率充放電, 蓄電エアコン, キャパシタバンクの切換えによる系統連系蓄電装置など を試作(2)した。太陽光と ECSへの貯藏と次世代住宅への 応用関連の研究では 2 年半にわたってキャパシタ蓄電シ ステムが高効率と少ない劣化状態を維持しつつメンテナ ンスフリーで運転を継続した成果が報告(8)されている。

さらに長時間 PS-B タイプの応用は国家プロジェクト 「負荷平準化新手法実証調査」(9)としても実施された。そ こでは二つのグループによってエネルギー密度 $27 \mathrm{Wh} / \mathrm{lit}$ の単セルなど各種キャパシタセルが試作され, $18 \mathrm{kF}, 1 \mathrm{lit}$ 単セルを 10 個直列にした $180 \mathrm{Wh}$ モジュール(図 7) と並列 モニタにバンク切換えを含むシステムとしての応用の可 能性も試された。補助金は役に立たぬという風説がある が, このプロジェクトの進展には干天の慈雨のように大 きく貢献した。
また, 短時間型 PS-L と ECS を用いたシリーズハイブ リッド大型バスが日産ディーゼル工業株)で試作され「クリ 一ンエネルギー自動車」国家プロジェクト成果発表会(10) での公表值で燃費低減率が従来の 1.8〜2.3 倍, ハイブリ ッド部だけによる改善効果が 1.8 倍に達した。乗用車より 使用条件の厳しい大型バスでキャパシタによる本格的な ハイブリッド車の可能性を実証したと言えよう。

\section{3 今後の課題と見通し}

研究を論文までで完成とするなら国家プロジェクトで の実証が終った時点で ECS は完成である。だが ECSの 商業化には未だ大きな課題が残つている。

それはコストである。研究の成果は既存品と同じ条件 を仮定し，たとえば鈶電池と同じ規模で生産した場合, キャパシタの寿命は，エネルギー密度は，值段は…… 評価する。研究者から見ると当然で, 量産中の電池と手 作りのキャパシタを比べたのでは不公平だからである。

既存の物と大差ない生産工程で作れる品なら，そこを 手掛かりにして比較的容易に立ち上れる。ECS の場合も 電子回路部には，いくら新技術を注ぎ込んでも問題ない。

ところが, 大型電気二重層キャパシタを量産するとな ると, 組立工場はもちろん活性炭工場や電解液工場まで 考える必要が起こった。工場から作るのはよいが果して それらは繁盛するか，償却できるか。大量に作れば安く なるが，量産工場が完成した頃になって新しいことを発 明されては困るから，今のうちに全部まとめて一遍に思 いつくようにと要求されている。

(平成 12 年 6 月 19 日受付)

著者写真と略歴 : 本誌学生のページ(1)参照

\section{文 献}

(1) 岡村迪夫 : 電気二重層キャパシタを用いた蓄電装置, 電学誌, 本号.

(2) 岡村迪夫 : 電気二重層キャパシタと蓄電システム, 日刊工業 新聞社, 初版, Mar., 1999.

(3) 例えば R. A. Sutula, "Electric and Hybrid Vehicle Energy Storage R\&D Programs of the U.S. Department of Energy", EVS-15, 1998.

(4) M. Okamura, et al:Method and Apparatus for Charging Electric Double Layer Capacitor. USP 5,498,951. 1996.

(5) 近藤潤次, 私信, 2000.6.

(6) 電気学会技術報告書 : 電気自動車の新しいエネルギー・制御 システム技術, 電気学会, 2000 .

(7) 竹内誠, 丸山孝道, 小池克己, 最上明矩 : 非多孔性炭素を用 いた高容量電気二重層キャパシ夕, 電気化学会大会, 2000.3.

(8) 新山信一郎, Om Romny, 中村宏一, 山城 迪, 三井克司, 山 岸政章, 岡村迪夫: 新型電力貯蔵装置 ECS を用いた PV-ECS システムの開発, 電学論 B, Vol. 120-B, No. 2, 2000.

(9) 新エネルギー・産業技術総合開発機構 : 負荷平準化新手法実 証調査 最終報告書, 2000.3.

(10) 佐々木正和 : LNG エンジン搭載ハイブリッドバスの開発, 高効率クリーンエネルギー自動車の研究開発成果発表会前别 り集, NEDO/自動車研究所, 2000.3 .22 . 